\title{
Problem and Prospect E-learning in Nigerian Universities
}

\author{
J. N. Anene, H. Imam, T. Odumuh \\ University of Abuja Nigeria, Nigeria
}

\begin{abstract}
This study was conducted to investigate e-learning in Nigerian University, the purpose was to determine the following: Availability of facilities for e-learning in Nigerian Universities, availability of e-learning materials in Nigerian Universities, if students make use of e-learning in their studies in Nigerian Universities. A total of two hundred and twenty eight students constituted the sample for the study in the six Geopolitical zones of Nigeria. Percentages statistic was employed in analysing data of the study. The findings of the study revealed that formidable obstacle to the use of information and communication technology is infrastructure deficiencies. Majority of the students reported that their Universities do not have e-learning library domain, no online seminars and no discussion with lecturers, no online examination, and there are limited bandwidth. The study recommended that the ongoing strike embarked by Academic Staff Union of Nigerian University (ASUU) should continue until these abnormalities are corrected by the Nigerian Government.
\end{abstract}

\section{Introduction}

In Nigeria, every year, about a million students apply for admission into various Universities in the country, but only about $10 \%$ of them get admitted into the Universities through Joint Admission and Matriculation Board (JAMB). The alternative to regular university schooling is e-learning. Unfortunately, the e-learning in Nigeria has not developed due to a number of factors which are as Oye et al. [9] observed ranges from mass unawareness, low computer literacy level and cost, these factors according them were identified as critical in affecting the acceptability of e-learning by students and lecturers of Nigerian universities. Despite the emerging technologies challenges, the traditional process of teaching and learning, and the way education is managed in Nigeria there is increasing awareness on the use of Information and Communication Technologies (ICTs) in teaching and learning.

Adomi and Kpangban noted that there are developments in the Nigerian education sector with regards to the application of ICT in institutions.
Technology enhanced learning, includes distance and online instruction, which are recognized as a viable tool necessary for preparing citizens to participate in the technologically driven global environment. The concepts computer-aided teaching and computer-aided learning have given birth to computer-aided instruction, which represents a combination of both teaching and learning.

Access to instruction through the internet is flexible, ensures broad viability and availability of educational opportunities. It is cost effective system of instruction and learning materials can be accessed irrespective of time and space. The use of ICT in education has become more and more popular globally.

E-learning according to Craige is the computer and network enabled transfer of skills and knowledge for the diffusion of innovative teaching [16]. E-learning according to Rosenberg is the process by which people acquire skills or knowledge for the purpose of enhancing their performance through the internet or intranet and multimedia which leads to reinforced learning by means of video, audio, quizzes and other forms of interaction. Ahmad [12] maintained that elearning is all about learning with the use of technologies presumably computers and other modern day tools. E-learning involves the use of electronic technology to deliver education and training, to monitor learner's performance and to report the learner's progress. Hedge and Hayward [8] view it as an innovative approach for delivering electronically mediated, well-designed, learner-centered and interactive learning environments to anyone, at any place, at anytime. Its success is mainly based on its benefits and distinctive features; it is easily accessible, cost efficient, gives students the flexibility of learning, it helps provide uniform delivery to all users reducing chances of misinterpretations, as well as promoting team learning and collaboration. ICT applied to education is being deployed in varying modes from sector to sector; these range from basic e-learning or distant learning to the use of small device such as mobile phones.

Education has shifted from the traditional form of education towards new methods of teaching and learning through the explosion of Information and 
Communication Technologies (ICT). The continuous advances in information technology have enabled the realization of a more distributed structure of knowledge transfer through the development of elearning. The developing countries have embraced ICT and consequently e-learning so as to keep pace with unimaginable speed in the area of technology. The use of ICTs in Nigeria and African countries generally is increasing and dramatically growing.

Economist Intelligence Unit in (2008) ranked Nigeria 62 among the nations in terms of the ability of a nation's institutions to use ICT to achieve their mission and vision [5]. Nigeria ranks below South Africa and Egypt - which ranked 39 and 57 respectively. Nigeria's e-readiness ranking highlights the need to seek innovative solutions to improve teaching and learning [2]. While there is a great deal of knowledge and information about how ICTs are being used in developed countries, there is not much information on how ICTs are being introduced into schools in developing countries [3]. In Nigeria, such recent developments and awareness of the government on Information and communication technology (ICT) have opened an opportunity for the adoption of elearning in delivering distance education (DE) for educating a vast mass of uneducated or less educated Nigerians [14].

\section{Literature Review}

During the past decade in more advanced industrialized nations, there has been a staggering amount of research and publication related to the use of ICT for educational purposes. Based on this, the study found it necessary to review the implementation of elearning in some developed and developing countries such as United Kingdom, United State of America and France for developed countries and Malaysia, Bangladesh and Nigeria.

In recent time, nearly everyone in the industrialized nations has gained access to ICT, and is computer literate. In the United State, the purchase of computers for school has been increasing in such a pace that is difficult to keep track of how many computer machines are now in American schools. Furthermore, there is a comprehensive survey of the instructional uses of computers in United States public and non-public schools. The report suggested that over one million computers were in American elementary and secondary schools and that more than fifteen million students used them during 1985, also half-a-million teacher used computers during the same period and that half of U.S. secondary schools (about 16,500 schools) owned 15 or more computers. Also, over 7500 elementary schools owned 15 or more computers. Considering that the figures quoted above were released almost two decade ago, there is no doubt that those figures would have increased tremendously by now [12].

United Kingdom has a long tradition of innovation in education; an example of such innovation is their Open University and Distance Learning (ODL) which was a model for many other countries and their open and distance learning institutions. Since the mid nineties United Kingdom have elaborated strategies and action plans to support ICT education; as examples is Ireland that proposed The Education Technology Strategy of Northern Ireland, the National Grid for Learning initiative was initiated in Scotland; Wales launched an e-learning strategy in 2001 and England councils and agencies were active in promoting innovative actions for better use of ICT at all level of education.

Realizing the needs to coordinate and share knowledge among states' initiatives, British Educational Communications and Technology agency (Becta) created in 1998 and redefined in 2003 to support all four UK education departments in their strategic ICT developments, facilitating knowledge transfer among them in order to encourage innovation and improvement, and bring coherence and synergy to UK-wide developments. Moreover, the Department for Education and Skills (DES), in UK and England are the government body responsible for all levels of education, including vocational education and training. In 2003, they conducted a national consultation aiming to "unify" e-learning strategies and benefit from experiences and collaborations of the many stakeholders. Consequently from this consultation emerged a national e-learning strategy. In a survey performed in the UK, it was found that a third of elearners do most of their e-learning in the comfort of their homes, while the majority of e-learning occurs at the workplace [9].

French government over the past decade has been pursuing a proactive policy aiming at increasing the use of information and communication technologies (ICT) in primary, secondary and higher education and, more broadly, at making Internet and ICT accessible to all French society. ICT is the emerging sector in France.

Distance learning is not a recent phenomenon to Malaysians, he advent of Internet in the early 1980's had resulted in a gradual introduction of e-learning to ODL students in Malaysia. E-learning initiatives in Malaysia are being undertaken mainly by universities, colleges and business enterprises. Private and public institutions of higher education as well as local and multinational corporations are the main players of elearning. Open University Malaysia (OUM) is the first main academic institution that leverages on e-learning to deliver its programmes in Malaysia [15]. According 
to Datuk and Ali [15] opined that in order to enhance the effectiveness of e-learning in Malaysia, there are many challenges that needs overcoming which are:

1. Awareness: Generally there is still a lack of awareness amongst the population, especially parents, of the effectiveness of e-learning. Many parents still feel that the traditional learning mode is better.

2. Low Adoption Rate: Most institutions are keen to embrace e-learning however. Nevertheless, issues like lack of e-content, inadequate infrastructure coupled with the problem of digital divide, has resulted in a relatively low adoption rate

3. Bandwidth Issue and Connectivity: Due to bandwidth and connectivity limitations, downloading of engaging content to the learners is always slow thereby creates frustration and boredom among learners and affects the ease of learning. Engaging content requires a rich combination of multimedia components.

4. Computer Literacy and Digital Divide: There is a large segment of the population that is computer illiterate in Malaysia, more especially the rural populace. This hinders the introduction and implementation of e-learning.

5. Lack of Quality E-Content: Most of the e-learning content has low interactivity and moderate impact on learners this is as a result of dearth of high quality elearning content in Malaysia. This is due to the lack of expertise as well as huge financial resources required to develop the content.

In Bangladesh the overall education sector is in the priority of the government. However, there is still a lot to develop in terms of reach, quality and contribution to the development process. In fact, many challenges facing Bangladesh are of old, low and uneven education participation, poor quality education, low per capital incomes, and a rapidly growing population that have been joined by new and more daunting challenges, including corruption, globalization, lack of political commitment, and rapidly advancing technology. In the area of introducing eLearning in Bangladesh, a small number of initiatives have already been introduced and most of the learning materials are developed in western countries with limited relevancy in terms of content and language [7].

In Nigeria the prospect of higher education in the near future relies on educational technologies. Recently, technology enhanced learning, including distance and online instruction, is been recognised as a viable tool necessary for preparing citizens to participate in the technologically driven global environment. However, research evidence has shown that Nigerian Universities are still lacking behind in information technology age. The environment necessary for the achievement and development of the ICT in Higher Institution, corporate and other areas of the economy are yet untapped. While there is growing demand for e-learning, the challenges are many. In the higher institutions in Nigeria, most lecturers and students are not knowledgeable in the use of computer, while some are beginning to know how to access their e-mail, some don't even have an email address. Olakulehin [6] noted that the infrastructures necessary for deploying an effective ICT platform is lacking in Nigeria. There isn't enough human skills and knowledge to fully integrate ICT into education. In line with these views, Aduwa-Ogiegbaen, and Iyamu [12] was emphatic that in Nigeria, a formidable obstacle to the use of information and communication technology is infrastructure deficiencies.

Mac-Ikemenjima [4] observed that there are inadequate ICT infrastructure including computer hardware and software, and bandwidth access; lack of skilled manpower to manage available systems and inadequate training facilities for ICT education at the tertiary level. In corroboration Oye et al. [9] added that, there are inadequate or non availability of internet access and limited bandwidth in some tertiary institutions. There are acute shortages of trained personnel who can perform the application of software, operating systems, network administration etc. Folorunso et al. [10] observed that mass unawareness, low computer literacy level and cost were identified as critical factors affecting the acceptability of e-learning by students and lecturers of Nigerian universities.

There are many key factors that hamper the successful implementation of ICT in developing countries especially Nigeria, however, only a few will be mentioned:

- Poor technical infrastructure: The technical infrastructure in developing countries is not highly developed, which means that phone-lines and Internet connections are unreliable or slow due to narrow bandwidth. Most users access the Internet in cyber cafes, with shared bandwidth, thus slow Internet connections, as not everyone has a personal computer or laptop. In Nigeria our problem is further worsened by the lack of adequate power.

- Financial restrictions: In developing countries the cost of ICT equipment can be a limiting factor with regards to reaching a broad target audience and making sure that everyone can afford this service. Also misappropriation of funds has added to the ongoing problem. 
- Lack of computer literacy: It has been found that low computer literacy level is a critical factor that affects the acceptability of ICT/e-learning by students and teacher in educational institutes. Furthermore the lack of ICT training for teachers and lecturers makes it hard for them to provide digital content, even when provided with all necessary infrastructures.

- Inappropriate teacher training: Unsuitable teacher training programs fail to engage teachers in using ICT in the preparation of their lessons. Teachers are the foundation to educating our pupils but times have changed and their lack of new knowledge / material has an immense effect on student learning.

- Internet connectivity: the cost of accessing the internet in Nigeria is still on the high side. Hence, some students find it a challenge to afford. Aduke suggested that the government should make Internet connectivity a priority for higher education to be able to leverage on the promises and opportunities ICTs present [1].

- Energy related problems: irregular and frequent interrupted power supply in Nigeria is a perennial problem affecting almost every aspect of the economy, including education. Ajadi et al. observed that it's been a major setback for technological advancement in the country [13]. Most rural areas in Nigeria are not even connected to the national grid. The consequence of this is that students residing in such areas may find it difficult to use ICT effectively.

- Limited expertise: There are few technical staff in most Universities to maintain the current system. Lack of, or inadequate trained personnel are a challenge to the use of ICT in higher institutions.

E-learning according to Oye et al. [9] refers to the use of ICTs to enhance and support teaching and learning process. E-learning ranges from the way student use e-mail and accessing course work online while following a course on campus to programs offered entirely online. E-learning allows for efficient transfer of knowledge anywhere and anytime, regardless of subject matter. It opens up a world of learning unavailable in most corners of the world, while at the same time empowering learners with the information technology awareness and skills crucial to succeed in today global knowledge economy. Ahmad, maintained that e-learning is all about learning with the use of technologies, presumably computers and other modern day tools [12].

\section{Research Rationale}

Despite the Nigerian Government efforts towards elearning by laying foundation for e-learning through investment in ICT infrastructure, management information systems, e-mail access and library information services for the last three decades through National Universities Commission. Nigeria still ranked as the $62^{\text {nd }}$ nation among other nations of the world, being the most populous country on the African continent; it ranks below South Africa and Egypt which rank 39 and 57 respectively in its use of ICT. In Nigeria, many institutions find it difficult to conceptualize and implement initiatives locally. Many factors have been identified as: lack of manpower, or technical infrastructure, financial restrictions, lack of computer literacy, poor power supply etc.

Whereas there is great deal of knowledge about how ICTs are being used in developed countries, there are dearths of information on how ICTs are being introduced into schools in developing. National Universities Commission (NUC) has provided ICT facilities to all federal universities known as National Universities Network (NUNet). The question still remains to how many Universities are aware of this service? Only recently that, staff and students of University of Abuja became aware that such facility had existed for over two years. There is no doubt that there is dearth on as to the statue of in e-learning in Nigerian Universities. It has therefore become necessary to carry out an empirical study in order to determine the effectiveness of e-learning in Nigerian Universities with a view suggesting how best to improve e-learning in Universities. The study was specifically conducted to investigate the following:

- Availability of facilities for E-learning in Nigerian Universities

- Availability of e-learning materials in Nigerian Universities

- If students make use of e-learning studies in Nigerian Universities.

Research questions raised by the study include the followings:

- Are there availability of facilities for elearning in Nigerian Universities?

- Are there availability of e-learning materials in Nigerian Universities?

- Do students make use of e-learning studies in Nigerian Universities?

A total of two hundred and twenty eight students constituted the sample for the study. A simple random 
sampling technique was employed in selecting thirtytwo Students from one of each Universities in the six Geo-political zones of Nigeria mainly: Anambra State University Uli, University of Port Harcourt, Ahmadu Bello University Zaria, University of Lagos, Federal University of Technology Minna, Federal University of Technology Yola and 68 students of the University Abuja in the Federal Capital Territory of Niger, and they constituted the sample for the study.

Questionnaire based on "Yes or No" and constituted the instrument for the study. Percentages were employed in analyzing the data that emanated in the study.

\section{Analysis of Findings}

Presentation, analysis and interpretation of the data based on the order of the research questions is carried out below:

Are there availability of facilities for e-learning in Nigerian Universities?

\section{Table 1. Availability of facilities for e-learning in Nigerian Universities}

\begin{tabular}{|l|l|l|l|l|l|l|}
\hline No & \multicolumn{1}{|c|}{ DESCRIPTION } & YES & $\%$ & NO & $\%$ & TOTAL \\
\hline 1. & Your university has an e-library domain. & 102 & 45 & 126 & 55 & 228 \\
\hline 2. & $\begin{array}{l}\text { You can check online learning resources on at least one of the following } \\
\text { Desktop computer, laptop computer, cell or mobile phone with MP3 } \\
\text { capability. }\end{array}$ & 122 & 54 & 106 & 46 & 228 \\
\hline 3. & $\begin{array}{l}\text { The online learning resource is compatible with at least one of the following } \\
\text { operating system, Win 98, Win 2000, Win XP, Win Vista, Mac OS, } \\
\text { Unix/Linux. }\end{array}$ & 130 & 57 & 98 & 43 & 228 \\
\hline 4. & $\begin{array}{l}\text { The online learning resource is compatible with at least one of the following } \\
\text { browser Netscape, Microsoft Internet Explorer, Mozilla Firefox, Google } \\
\text { chrome. }\end{array}$ & 130 & 57 & 98 & 43 & 228 \\
\hline 5. & $\begin{array}{l}\text { My bandwidth is limited. } \\
6 .\end{array}$ & 126 & 5 & 102 & 49 & 228 \\
\hline My electricity supply is limited. & 127 & 56 & 101 & 44 & 228 \\
\hline
\end{tabular}

Table 1 shows availability of facilities for elearning in Nigerian Universities. 102 students answered yes representing $45 \%$ as against 126 students who answered no representing $55 \%$ to the question "Your University has an e-library domain". 122 students answered yes representing 54\% as against 106 students who answered no representing $46 \%$ to the question "You can check online learning resources on at least one of the following Desktop computer, laptop computer, cell or mobile phone with MP3 capability". 130 students answered yes representing 57\% as against 98 students who answered no representing $43 \%$ to the question "The online learning resource is compatible with at least one of the following operating system, Win 98, Win 2000, Win XP, Win Vista, Mac OS, Unix/Linux". The same response as question 3 went for question 4. 116 students answered yes representing $51 \%$ as against 112 students who answered no representing 49\% to the question "My bandwidth is limited", and finally, 127 students answered yes representing $56 \%$ as against 101 students who answered no representing $44 \%$ to the question "My bandwidth is limited".

Are there availability of e-learning materials in Nigerian Universities? Table 2 shows availability of materials for e-learning in Nigerian Universities. 117 students answered yes representing $51 \%$ as against 111 students who answered no representing $49 \%$ to the question "A clear statement of all online based course requirements was provided at the beginning of the course". 105 students answered yes representing 46\% as against 113 students who answered no representing $54 \%$ to the question "A complete list of required and recommended learning and reference material was provided in your online learning hub". 
Table 2. Availability of E-learning materials in Nigerian Universities

\begin{tabular}{|r|l|c|c|c|c|l|}
\hline No & \multicolumn{1}{|c|}{ DESCRIPTION } & YES & $\%$ & NO & $\%$ & TOTAL \\
\hline 1. & $\begin{array}{l}\text { A clear statement of all online based course requirements was } \\
\text { provided at the beginning of the course. }\end{array}$ & 111 & 49 & 117 & 51 & 228 \\
\hline 2. & $\begin{array}{l}\text { A complete list of required and recommended learning and reference } \\
\text { material was provided in your online learning hub. }\end{array}$ & 46 & 113 & 54 & 228 \\
\hline 3. & Your university has educational software for teaching. & 102 & 45 & 116 & 55 & 228 \\
\hline 4. & All online learning materials and resources were understandable. & 82 & 36 & 120 & 64 & 228 \\
\hline 5. & The online materials were interesting and engaging. & 89 & 39 & 139 & 61 & 228 \\
\hline 6. & The course activities helped me learn. & 97 & 31 & 131 & 69 & 228 \\
\hline
\end{tabular}

102 students answered yes representing $45 \%$ as against 116 students who answered no representing $55 \%$ to the question "Your university has educational software for teaching". 82 students answered yes representing $36 \%$ as against 120 students who answered no representing $64 \%$ to the question "Your university has educational software for teaching". 89 students answered yes representing 39\% as against 139 students who answered no representing $61 \%$ to the question "The online materials were interesting and engaging" and finally, 97 students answered yes representing $31 \%$ as against 131 students who answered no representing $69 \%$ to the question "The course activities helped me learn.

Do students make use of e-learning studies in Nigerian Universities?

Table 3. Use of e-learning by students in Nigerian Universities

\begin{tabular}{|c|l|l|l|l|l|l|}
\hline No & DESCRIPTION & YES & $\%$ & NO & $\%$ & Total \\
\hline 1 & $\begin{array}{l}\text { You engage in online seminars and discussion with your lectures } \\
\text { weekly. }\end{array}$ & 100 & 44 & 128 & 56 & 228 \\
\hline 2 & All my online Instructors or tutors could be contacted easily. & 102 & 45 & 116 & 55 & 228 \\
\hline 3 & You receive lectures online weekly. & 98 & 43 & 120 & 57 & 228 \\
\hline 4 & You receive and submit assignment online & 77 & 34 & 151 & 66 & 228 \\
\hline 5 & You sit for examination online & 91 & 40 & 137 & 60 & 228 \\
\hline
\end{tabular}


Table 3 shows if students make use of e-learning studies in Nigerian Universities. 100 students answered yes representing $44 \%$ as against 128 students who answered no representing $56 \%$ to the question "You engage in online seminars and discussion with your lectures weekly". 102 students answered yes representing $45 \%$ as against 113 students who answered no representing 55\% to the question "All my online Instructors or tutors could be contacted easily". 98 students answered yes representing $43 \%$ as against 120 students who answered no representing $57 \%$ to the question "You receive lectures online weekly". 77 students answered yes representing $34 \%$ as against 151 students who answered no representing $34 \%$ to the question "You receive and submit assignment online". 91 students answered yes representing $40 \%$ as against 137 students who answered no representing $60 \%$ to the question "You sit for examination online

\section{Discussion}

With regards to infrastructure, the finding of the study revealed that majority of the student reported that their Universities do not have e-learning library domain, that their bandwidth were limited and that their electricity supply was limited. This finding is in corroboration with that of Olakulehin, who noted that infrastructures necessary for deploying an effective ICT platform is lacking in low-income countries like Nigeria [6]. In Nigeria, a formidable obstacle to the use of information and communication technology is infrastructure deficiencies. However, majority of the students said they can check their online learning resources on at least one of the following: desktop computer, laptop computer, cell or mobile phone with MP3 capability, that online learning resource is compatible with at least one of the following operating system, Win 98, Win 2000, Win XP, Win Vista, Mac OS, Unix/Linux" and that the online learning resource are compatible with at least one of the following browser Netscape, Microsoft Internet Explorer, Mozilla Firefox, Google chrome. This finding buttress Adomi and Kpangban statement that there are developments in the Nigerian education sector as regards to the application of ICT in schools.

With regards to availability of materials for elearning in Nigerian Universities, majority of the students said that a clear statement of all online based course requirements were not provided at the beginning of the course, complete list of required and recommended learning and reference material were not provided in online learning hub, university has no educational software for teaching, the online materials were not interesting and engaging, and that finally, the course activities did not help them learn. The reason for this could be the inadequate ICT infrastructures, such as computer hardware and software high [4]. Oye et al. observed that, there is non-availability of internet access in some tertiary institutions because of the recurrent cost of bandwidth [9].

With regards to if students engage in e-learning in Nigerian Universities, majority of the students reported that they do not engage in online seminars and discussion with their lectures weekly, that they do not easily contact their online instructors or tutors, they do not receive lectures online weekly, they do not receive and submit assignment online and finally, they do not sit for examinations online. Reason could be as Folorunso et al. observed that mass unawareness, low computer literacy level and cost were identified as critical factors affecting the acceptability of e-learning by students and lecturers of Nigerian universities [10].

\section{Conclusion}

The study concludes that there are developments in the Nigerian education sector as regards to the application of ICT in schools, such recent developments and awareness has opened an opportunity for the adoption of e-learning in delivering distance education (DE) for educating a vast mass of uneducated or less educated Nigerians. However, the challenges are many, infrastructures such as computer hardware and software high, and bandwidth/access necessary for deploying an effective ICT platform was lacking in Nigeria. There isn't enough internet access in some tertiary institutions. There are acute shortages of trained personnel who can perform application of software, operating systems, network administration. For the past fifteen years Nigeria has been having difficulty providing stable and reliable electricity supply to every nook and cranny of the country.

Based on the conclusion, the study recommends that that:

1. The Nigerian Government should make concerted effort to provide the enabling environment, by establishing e-learning facilities in all Universities.

2. It should be made mandatory for all lecturers and students to have computer, way of providing soft loan either by institutions or Government of Nigeria.

3. Student should not graduate in their field of study without acquiring a certificate of the computer literacy course.

4. Computer certificate should be the first on the list of lecturers' promotion requirements. 


\section{References}

[1] Aduke, A. F., (2008). Usage and challenges of information and technology (ICT) in teaching and learning in Nigerian universities. Asian Journal of Information Technology, 7(7), 290-295.

[2] A. Tella A. Tella, O. M., Toyobo, L. O Adika, and A. A. Adeyinka, "An assessment of secondary school teachers uses of ICT'S: implications for further development of ICT'S use in Nigerian secondary schools. 2 (2), March Copyright (C) 2012 SAVAP International, www.savap.org.pk.

[3] C. M. Beukes-Amiss, and E.R.T. Chiware, "The impact of diffusion of ICTs into educational practices, how good or how bad?" A review of the Namibia situation. Available at: http://www.dspace.unam.na:8443/dspace/bitstream/1995/244 /impact+diffusionICTedupdf. Retrieved on the 10 February 2007.

[4] D. Mac-Ikemenjima, e-Education in Nigeria: Challenges and Prospects. Being a presentation at the 8th UN ICT Task Force Meeting, Dublin, Ireland, (2005).

[5] Economist Intelligence Unit in (2008)

[6] F. K. Olakulehin, "Information communication technologies in teachers training and professional development in Nigeria." Turkish Journal of Distance Education (TODJE) 8, (1), (2007), 133- 142.

[7] M. S. U. Akbar, eLearning in developing countries: Challenges and opportunities: Bangladesh perspective proceedings of the second international conference on elearning for knowledge-based society, August 4-7, 2005, Bangkok, Thailand.

[8] N. Hedge, and L. Hayward, " Redefining roles. University e-learning contributing to Life-long learning in a networked world". E-Learning, Journal of the Nigerian cartography Association. 771, (2004), 128 - 145.

[9] N.D. Oye, M. Salleh and N. A. Iahad, "Challenges of eLearning in Nigerian: University education based on the experience of developed countries" International Journal of Managing Information Technology (IJMIT) 3(2) (2011), p 39-48.

[10] O. Folorunso, O.S. Ogunseye and S.K. Sharma, "An exploratory study of the critical factors affecting the acceptability of e-learning in Nigerian universities". Information Management and Computer Security Journals, 14 (5), (2006), 496-505.

[11] S. A. Ahmad, "Essentialities for e-learning: the Nigerian tertiary Institutions in question": Academic Research International. 2 (2), (2012), pp $286-219$.

[12] S. E. Aduwa-Ogiegbaen, and E. O. S. Iyamu, "Using Information and Communication Technology in Secondary
Schools in Nigeria: Problems and Prospects". Educational Technology \& Society, 8 (1), (2005), 104-112.

[13] T.O. Ajadi, I.O. Salawu and F.A. Adeoye, "E-learning and distance Education in Nigeria". The Turkish Online Journal of Educational Technology, 7(4), (2008).

[14] Ajadi T.O., Salawu, I.O. and Adeoye, F.A., (2008). Elearning and distance Education in Nigeria. The Turkish Online Journal of Educational Technology, 7(4), Article 7.

[15] T.S Datuk, and A. Ali, Issues \& challenges in implementing e-learning in Malaysia: Open University Malaysia. (2012), Copyright (c) UNITEM Sdn. Bh.

[16] W. Craig, Overview of the e-learning capital programme, http://www.jisc.ac.uk/media/documents/ programmes/capital/elearningprogramme_craigwentworth.pd f (2007). 